\title{
Incorporating critical fault properties controlling hydrocarbon accumulation in 3D basin and petroleum system modelling: a case study in the northern North Sea
}

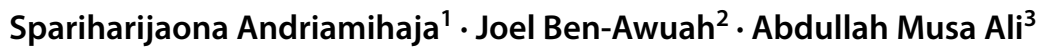

Received: 17 March 2018 / Accepted: 29 March 2019 / Published online: 5 April 2019

(c) The Author(s) 2019

\begin{abstract}
Fault properties are very important parameters in migration and accumulation of hydrocarbons in sedimentary basins. However, there are still several different schools of thought on how to incorporate such prospect-bounding fault properties into petroleum system migration and modelling studies. This paper investigates how shale gouge ratio (SGR), which defines the sealing/non-sealing capacity of faults, can be incorporated in basin modelling using the Gullfaks, Visund, Kvitebjorn and Huldra fields in the northern North Sea as a case study. The paper also presents the results from the most likely model representing the present day reality in the basin by varying the faults properties defined by SGR until the reserves-in-place in the four fields are obtained. Our results show that gas accumulations are more sensitive to SGR than the oil accumulations. The oil accumulation in the Gullfaks field is controlled by three main faults. The first fault bounding the field is a non-sealing fault with SGR $=10 \%$. The second fault located further south in the field is a sealing fault, and the third fault located in the north is a non-sealing fault. A NE-SW non-sealing trending fault controls the hydrocarbon accumulation in the Visund field. In the Kvitebjørn field, another NE-SW trending fault surrounding the field with an SGR of 30\% controls the hydrocarbon accumulation. The gas-in-place in the Huldra field is controlled by two $\mathrm{N}-\mathrm{S}$ trending faults. The first fault is located in the west of the field and is defined by SGR of $40 \%$, while the second fault is defined as open. Analysis of the burial history curves of the most likely petroleum system model obtained after the fault properties modelling shows that the Late Jurassic to Early Cretaceous uplift in the basin is more pronounced in the footwall of the triple rift graben system in the basin. In the same period, the axis of the graben system is characterized by non-deposition of sediments.
\end{abstract}

Keywords Faults $\cdot$ Shale gouge ratio $\cdot$ North Sea $\cdot$ Basin modelling

\section{Introduction}

One of the key elements that control hydrocarbon accumulation and migration is the faulting system (Ben-Awuah et al. 2013; Ben-Awuah et al. 2014). Lateral migration of

Spariharijaona Andriamihaja

andriamis@yahoo.fr

1 Hydrocarbon Recovery and Technology, Group Research and Technology, PETRONAS Research Sdn Bhd, Jalan Ayer Itam, Kawasan Institusi Bangi, Kuala Lumpur 43000, Selangor, Malaysia

2 Department of Applied Geology, Faculty of Engineering and Science, Curtin University Malaysia, CDT 250, 98009 Miri, Sarawak, Malaysia

3 Department of Geology, Faculty of Earth and Environmental Sciences, Bayero University, Kano, Nigeria hydrocarbons can be impeded by faults by juxtaposing lithologies against reservoir/carrier units or by forming a layer of high capillary threshold pressure fault rock (Childs et al. 2009). During faulting, sediments adjacent to the faults are crushed creating a shale gouge (Yielding et al. 1997). In clastic sequences, fault seals/contacts are most commonly attributed to dragging of clay, or shale, into faults to form clay smears (Lindsay et al. 1993; Fulljames et al. 1997; Yielding et al. 1997; Davies et al. 2003). A fault can be defined either as closed or opened or partially opened by measuring the amount of clay along the fault. An open fault is non-sealing and allows migration through it, whereas a closed fault is sealing and does not allow migration through it. Yielding et al. (1997) introduced the term shale smear factor (SSF) or shale gouge ratio (SGR) to define the amount of clay along the fault. The ratio between the amount of small grains $(D<10 \mathrm{~nm})$ and large grains along faults can 
be expressed by the SGR. SSF and SGR in addition to juxtaposition and fault throw also depend on the lithology of the faulted rocks. Hantschel and Kauerauf (2009) proposed the relation between SGR and fault capillary pressure (FCP) as shown in Eq. 1. A fault is therefore defined as an open fault when SGR is less than $18 \%$ or FCP is less than $0.1 \mathrm{MPa}$. It is defined as a closed fault when SGR is greater than $95 \%$ or FCP is greater than $50 \mathrm{MPa}$.

$\mathrm{FCP}=k(\mathrm{SGR}-0.18), \quad$ with $k \geq 50 \mathrm{MPa}$

$k$ : permeability.

Methods of incorporating fault and seal properties in hydrocarbon migration studies have evolved significantly over time (Perkins 1961; Lindsay et al. 1993; Yielding et al. 1997; Davies et al. 2003; Childs et al. 2009) and focused mainly on the shale content in faults separating juxtaposed reservoirs in migration modelling and fault seal studies. However, there are still opposing views on the best methods to use to properly account for the impact of fault properties in hydrocarbon accumulation and migration studies. In this study, a method of incorporating fault properties in petroleum systems modelling using the SGR concept is proposed. The method has been applied to the Kvitebjorn, Gullfaks, Huldra and Visund fields in the northern North Sea simultaneously to determine the most probable model that accounts for the different volumes of hydrocarbon accumulation in each of the four fields. The approach employed in this study involves varying the SGR values and comparing modelled hydrocarbon accumulation results to actual hydrocarbon accumulations in the four fields. The SGR values are varied, and the sensitivity of the modelling results to the variation tested until the hydrocarbon volumes obtained from the modelling is similar to the actual hydrocarbon volumes. The strength of this approach over other methods is that the sensitivity of the fault models to the SGR variation is tested on the hydrocarbon accumulation in all the four fields simultaneously.

\section{Geological setting and petroleum system}

The North Sea is one of the most productive hydrocarbon provinces in the world. At its peak in 1996, the area produced $9 \%$ of the world's oil and was the fourth largest producing region (Zanella and Coward 2003). The northern North Sea is well suited for such a study due to the presence of large rotated fault blocks associated with lithospheric extension and crustal thinning in the basin. Most of the traps in the basin developed as rotated fault blocks as a result of the rifting that affected the area. The study area is located in quadrants 30 and 34 of the northern North Sea (Fig. 1a).

Structures which shaped the central and northern North Sea comprise both those which formed the crustal framework and those that subsequently reworked that framework into the present day configuration (Zanella and Coward 2003). The North Sea rift system is a triple system that forms the Viking Graben, Central Graben and the Moray Firth basins. According to Zanella and Coward (2003), the main pulses of Mesozoic and Cenozoic deformation that shaped the structural framework of the northern North Sea are summarized below:

1. Permo-Triassic rifting

2. Thermal uplift and volcanism during the Mid-Jurassic

3. Late Jurassic to Early Cretaceous rifting including a possible change in direction of extension from $\mathrm{E}-\mathrm{W}$ to NW-SE

4. Cretaceous to Cenozoic thermal subsidence

5. Cretaceous to Cenozoic pulses of tectonic inversion

6. Cenozoic uplift of the basin margins.

Evidence for regional uplift affecting the North Sea during Toarcian to early Aalenian times comes from stratigraphic data and regional well correlations that have been used to define the form of the Mid-Jurassic unconformity (Underhill and Partington 1993). This uplift allowed erosion down to Lower Jurassic or Triassic strata. Erosion of the uplifted area yielded Bajocian to Bathonian sands that now form the important Brent Group reservoirs of the northern North Sea (Zanella and Coward 2003).

In the northern North Sea of the Norwegian Continental Shelf, seven main petroleum plays have been defined by the Norwegian Petroleum Directorate ranging from Carboniferous to Miocene in age. One of the most important petroleum plays with several discoveries and fields is the Upper Triassic to Middle Jurassic Play. It includes most of the discovered fields in this region, such as Visund, Gullfaks, Kvitebjørn and Huldra fields which have been selected for this study.

In this play, the generated hydrocarbons are sourced from Draupne Formation which is Upper Jurassic in age and was deposited in marine and anoxic environment (Vollset and Dore 1984) (Fig. 1b). This formation is characterized by brownish black shale, rich in organic matter with total organic carbon (TOC) varying from 2 to $10 \%$ and hydrogen index (HI) between 200 and $600 \mathrm{mg} / \mathrm{gTOC}$ (Kubala et al. 2003). According to Kubala et al. (2003), Draupne Fm reached the maturity for oil generation in the axis of Viking Graben in Late Cretaceous. The peak oil maturity is attained when the burial depth exceeds $3000 \mathrm{~m}$ at about $54 \mathrm{Ma}$ with temperature starting around $110{ }^{\circ} \mathrm{C}$ and gas window is at $14 \mathrm{Ma}$ (Moretti and Deacon 1995; Kubala et al. 2003).

Two reservoir units are found in the Triassic and Middle Jurassic play. The first and older unit is Statfjord Formation (Triassic to Lower Jurassic) and mainly consists of coarsegrained sandstones deposited in alluvial plains and braided 


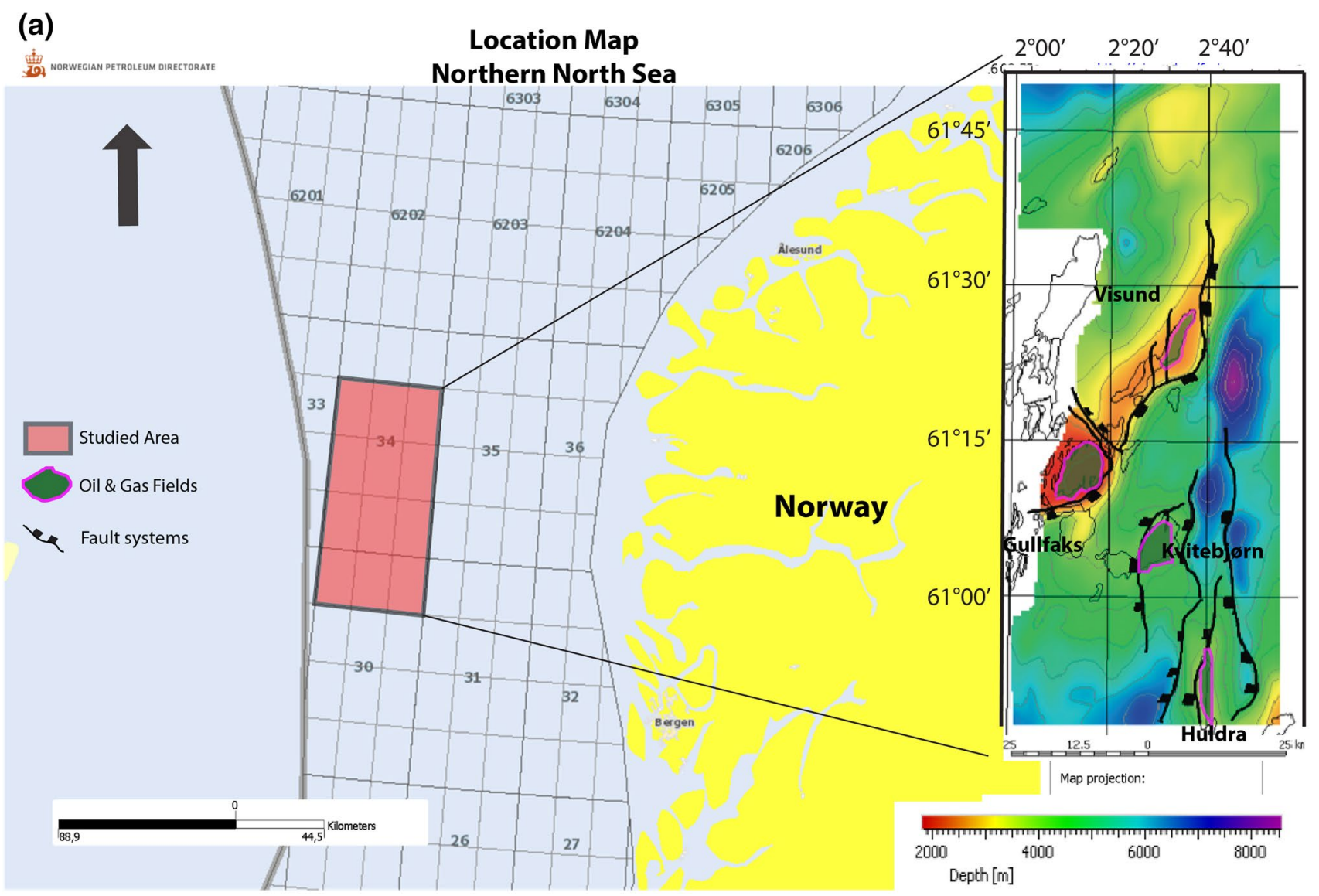

Fig. 1 a Location map of study area showing quadrants 30 and 34 in the northern North Sea (the location map has been modified to include coordinates). b Lithostratigraphic chart of the North Sea (Halland and Riis 2014)

streams (Kirk 1979; Røe and Steel 1985). This reservoir unit exhibits excellent porosity (20-24\%) and permeability (300 mD to $2000 \mathrm{mD}$ ) (Johnson and Krol 1984). The second main reservoir is the Brent Group which is Middle Jurassic in age. This reservoir unit also shows excellent petrophysical parameters with porosity ranging $20-30 \%$ and permeability from 50 to $5000 \mathrm{mD}$ at depth less than $3000 \mathrm{~m}$.

These reservoirs are developed in tilted fault blocks as a result of rifting tectonic events affecting the area. The structures where some of the fields such as Gullfaks occur are very complex and associated with a series of faults (Dahl and Solli 1993). These fields are also controlled by the fault reactivations during Mesozoic period (Johnson and Fisher 1998). To ensure the accuracy of the model in this study, all of these previous literature discussed above on the petroleum system of the study area have been considered and incorporated into the model.

Most of the rotated fault traps relating to Lower and Middle Jurassic plays in the basin have Upper Jurassic shales as cap rocks. In the areas where intense erosion has affected the footwall crests, Lower Cretaceous and in some cases Upper Cretaceous shales form top seals of the trap. The bottom seals of the Middle Jurassic reservoir hydrocarbon accumulation consist of low permeability Lower Jurassic shales. The same low-permeability rocks form parts of the top seal to the Lower Jurassic hydrocarbon accumulations in reservoirs such as the Cook and Statfjord Formations, which are sealed by the Dunlin Group shales down-dip or by Upper Jurassic or Lower Cretaceous shales on the eroded highs (Husmo et al. 2002). For instance, in the Gullfaks and Statfjord fields, most of the traps are bounded by large faults across which the reservoir is commonly juxtaposed against impermeable Upper Jurassic shales (Husmo et al. 2002).

\section{Methodology}

\section{Model construction}

Prior to simulation, the 3D model is reconstructed from interpreted horizons and fault system maps derived from 3D seismic data of the study area. The maps used in this modelling were provided by SINTEF Petroleum Research, Trondheim, Norway. Once the layers were created and the 


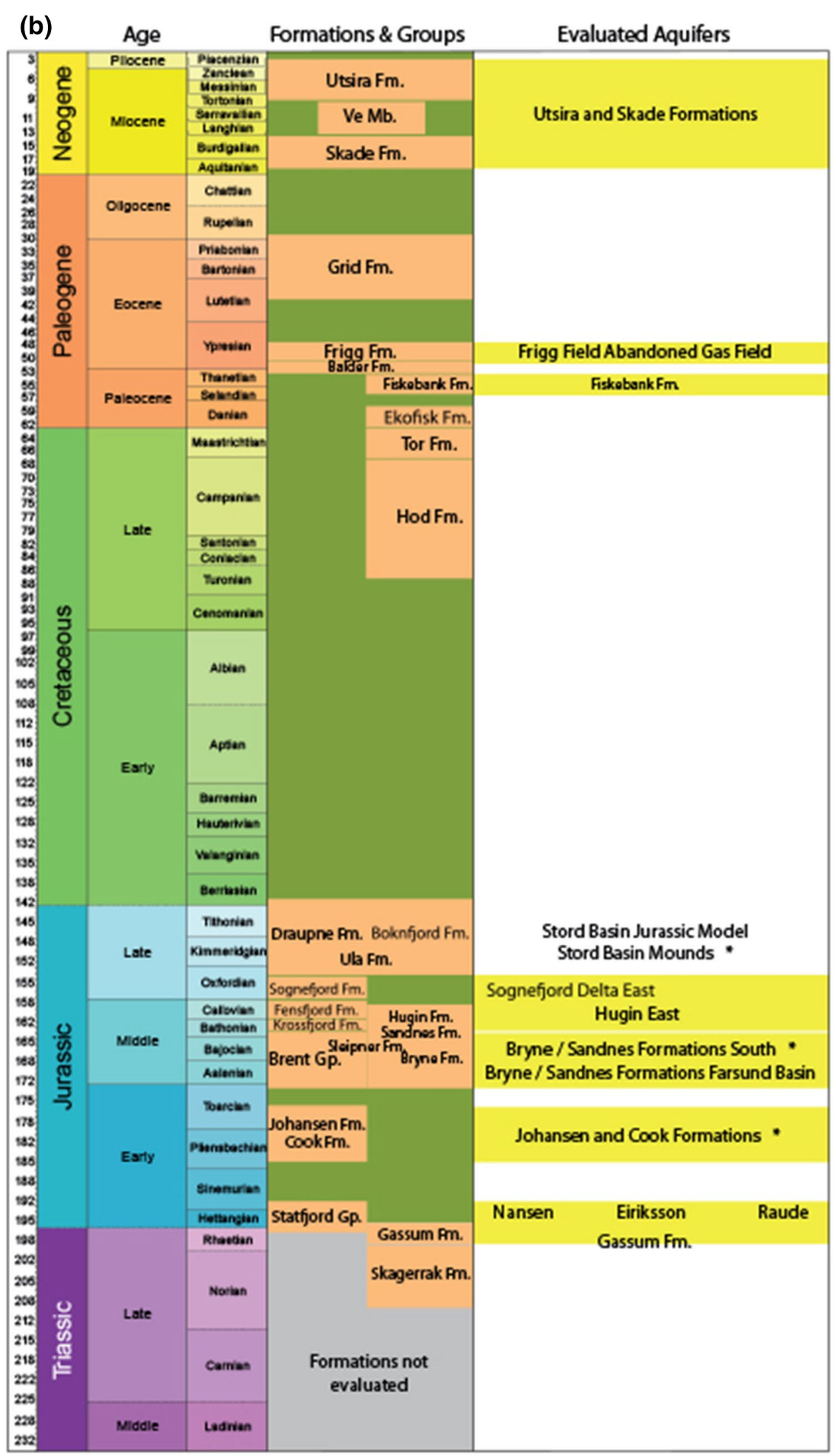

* Evaluated prospects

Fig. 1 (continued) 
model was built, its accuracy was validated by calibrating it with five exploration wells (well 31/4-5; 34/8-6; 34/8-7; 34/11-3 and 34/11-4) in the basin that intersects the petroleum system in the studied fields. In order to further constrain the developed models, other calibration parameters such as vitrinite reflectance and bottom hole temperature data are integrated into the model. These data are kept constant throughout the different scenarios with only the fault parameters being varied.

\section{Facies deposition, definition and erosion}

Deposition of sediments in the basin is the first process modelled in the reconstruction of the basin. Deposition of specific layers is assigned to geological events in the basin within a specific period with the first layer deposited being the oldest layer. Each layer represents a particular facies defined by a combination of lithology and a particular petroleum system element. The source rock property is defined by TOC, HI and the type of kinetics model. Another process is the erosion. In this modelling, erosion has been defined as the event where sediments deposited previously are removed. The amount of eroded sediment can be calculated using the following equation (Eq. 2) (Table 1):

$D_{\text {eroded }}=D_{\text {initial thickness }}-D_{\text {present day }}$

Each layer in the model is assigned to a specific facies. These input data are the most important parameter in basin modelling because it defines the petroleum system elements of the model. In this project, the Draupne and Heather Fms are set as source rocks and the Brent Group and the Statfjord Fm are defined as reservoirs (Fig. 1b). The layers above Draupne Fm are set as overburden rock, and the Dunlin Group which is below Brent Group is set as underburden rock. In terms of source rock properties, the distribution of

Table 1 Eroded sediments intervals and thicknesses

\begin{tabular}{ll}
\hline Interval depth $(\mathrm{m})$ & $\begin{array}{l}\text { Eroded } \\
\text { sediments } \\
(\mathrm{m})\end{array}$ \\
\hline$Z<2300$ (Gullfaks) & 800 \\
$2300-2800$ & 400 \\
$2800-3300$ & 350 \\
$3300-3800$ & 300 \\
$3800-4300$ & 250 \\
$4300-4800$ & 200 \\
$4800-5300$ & 150 \\
$5300-5800$ & 100 \\
$5800-6300$ & 50 \\
$Z>6300$ & 0 \\
\hline
\end{tabular}

TOC and HI is uniform within the area and the kinetic model used is the Burnham (1989) _TII kinetic model.

Nine horizon maps representing nine layers have been imported into the model. The age of each layer is defined by the period of deposition and erosion. The oldest layer in the model is the Statfjord Fm deposited from 204 to $190 \mathrm{Ma}$. The uplift occurs from 150 to $135 \mathrm{Ma}$ and is associated with the Draupne Fm (Nadin and Kusznir 1995; Underhill and Partington 1993). The project is focused on the Lower-Middle Jurassic play in the northern North Sea and so the Draupne, Heather Fms and the Brent group layers need to be created. The layer between Base Cretaceous and Top Middle Jurassic horizons is subdivided into Draupne and Heather Fms, and the layer between Top Middle Jurassic and Top Statfjord into Brent and Dunlin Groups (Table 2).

The present day thickness of Draupne Fm is the result of a combination of syn-rift deposition and erosion affecting the top of the formation. This erosion is more pronounced in the footwall of the graben, and decreases towards the axis of the graben. It is difficult to constrain the thickness of Draupne Fm sediments eroded during the uplift phase. The erosion data used in this project are obtained from previous work in the northern North Sea by Spencer and Larsen (1990). The thickness of eroded sediments in Gullfaks is estimated to be $800 \mathrm{~m}$. Based on these data, it is assumed that the erosion decreases gradually with depth. The distribution of erosion thickness is set as $50 \mathrm{~m}$ above $2300 \mathrm{~m}$ (boundary depth of Gullfaks field) and with a regular increase in depth of $500 \mathrm{~m}$ until $6300 \mathrm{~m}$.

\section{Boundary conditions}

In basin modelling, the paleo-heat flow can be predicted by crustal model. The model used in this work is the McKenzie model. It considers the effects of rifting phases. The lithosphere is extended and thinned by a stretching event. In this model, the amount of thinning of the crust and the upper mantle is different and defined, respectively, by $\beta$-crust and $\beta$-mantle. The McKenzie model takes into account two main phases:

- An initial stretching phase corresponds to the rifting phase. This phase is characterized by an exponential increasing of heat flow and rapid subsidence

- A cooling phase corresponds to thermal subsidence. This second phase shows a gradual decreasing of heat flow and slow subsidence.

The paleo-heat flow is also a function of the stretching factors of the crust ( $\beta$-crust) and the mantle ( $\beta$-mantle). The $\beta$-crust varies from 1.188 to 1.75 with an average of 1.4 (Fig. 2a). The $\beta$-mantle varies from 1.23 to 1.98 with an average of 1.6 (Fig. 2b). As the stretching factor of the crust

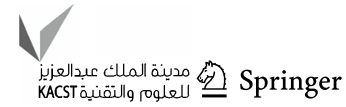


Table 2 Facies and petroleum system elements definition

\begin{tabular}{|c|c|c|c|c|c|c|c|c|c|}
\hline \multicolumn{2}{|l|}{ Age } & \multirow{2}{*}{$\begin{array}{l}\text { Group/forma- } \\
\text { tion }\end{array}$} & \multirow{2}{*}{$\begin{array}{l}\text { Petroleum } \\
\text { System }\end{array}$} & \multicolumn{4}{|l|}{ Lithology } & \multirow{2}{*}{ TOC (\%) } & \multirow{2}{*}{$\begin{array}{l}\text { HI } \\
\text { (mgHC/ } \\
\text { gTOC) }\end{array}$} \\
\hline Start & End & & & $\begin{array}{l}\text { Sandstone } \\
(\%)\end{array}$ & Siltstone (\%) & Shale $(\%)$ & $\begin{array}{l}\text { Lime stone } \\
(\%)\end{array}$ & & \\
\hline $\begin{array}{l}\text { Middle Mio- } \\
\text { cene }\end{array}$ & Recent & Nordland & Overburden & 80 & 20 & & & & \\
\hline Eocene & $\begin{array}{l}\text { Early Mio- } \\
\text { cene }\end{array}$ & Hordaland & Overburden & 50 & & 50 & & & \\
\hline Paleocene & Early Eocene & Rogaland & Overburden & & 20 & 80 & & & \\
\hline $\begin{array}{l}\text { Late Creta- } \\
\text { ceous }\end{array}$ & $\begin{array}{l}\text { Early Pale- } \\
\text { ocene }\end{array}$ & Shetland & Seal & & 90 & & 10 & & \\
\hline $\begin{array}{l}\text { Early Creta- } \\
\text { ceous }\end{array}$ & $\begin{array}{l}\text { Late Creta- } \\
\text { ceous }\end{array}$ & CromerKnoll & Seal & & 5 & 65 & 30 & & \\
\hline Late Jurassic & $\begin{array}{l}\text { Early Creta- } \\
\text { ceous }\end{array}$ & Draupne & Source Rock & & & 100 & & 6 & 398 \\
\hline $\begin{array}{l}\text { Middle Juras- } \\
\text { sic }\end{array}$ & Late Jurassic & Heather & Source Rock & & & 100 & & 2 & 131.5 \\
\hline $\begin{array}{l}\text { Middle Juras- } \\
\text { sic }\end{array}$ & $\begin{array}{l}\text { Middle Juras- } \\
\text { sic }\end{array}$ & Brent & Reservoir & 95 & & 5 & & & \\
\hline Early Jurassic & $\begin{array}{l}\text { Middle Juras- } \\
\text { sic }\end{array}$ & Dunlin & Underburden & & 80 & 20 & & & \\
\hline Late Triassic & Early Jurassic & Statford & Reservoir & 100 & & & & & \\
\hline
\end{tabular}

and the mantle reaches the highest value in the axis of the grabens, it is expected to have higher heat flow compared to the other part of the basin resulting in a more mature source rock.

After simulation, the paleo-heat flow at 165 Ma ranges from 63.34 to $68.81 \mathrm{~mW} / \mathrm{m}^{2}$. At $155 \mathrm{Ma}$ where the rift started, it ranges from 65.8 to $77.1 \mathrm{~mW} / \mathrm{m}^{2}$ (Fig. 3a). At the end of the rifting phase (135 Ma), the heat flow reaches its peak with values between 68.9 and $94.4 \mathrm{~mW} / \mathrm{m}^{2}$ (Fig. 3b). During the thermal cooling phase $(65.5 \mathrm{Ma})$, it ranges from 61.6 to $64.98 \mathrm{~mW} / \mathrm{m}^{2}$ (Fig. 3c). At the end of the thermal cooling (2.6 Ma) until the present day, the heat flow varies from 60.98 to $58.67 \mathrm{~mW} / \mathrm{m}^{2}$ (Fig. 3d).

Other boundary conditions used in building the model are the paleo-water depth and temperature of surface water interface. The paleo-water depth is obtained from previous studies (Kyrkjebø et al. 2004) and varies between 0 and $410 \mathrm{~m}$.

The paleo-surface water interface temperature (SWIT) was defined using an integrated PetroMod tool that considers the paleo-water depth and the evolution of ocean surface temperatures over time based on the paleo-latitude of the area (Hantschel and Kauerauf 2009). The temperature was kept constant at $25^{\circ} \mathrm{C}$ from the Devonian to Cretaceous period and then varied between 16 and $23{ }^{\circ} \mathrm{C}$ in the Tertiary and Quaternary periods (Evans et al. 2003).

\section{Compaction model}

In constructing the model, another factor incorporated in the model is compaction caused by overburden load. The software used has inbuilt compaction models for different lithologies. The model used in this study is “Athy's law with hydrostatic depth model" (Eq. 3). It is a model defined by mathematical equation of porosity as a function of depth. It assumes hydrostatic pressure and deposition of entire column with the same lithology. In order to determine the Athy's law parameters, the compaction model is calibrated with the average porosity of the reservoir rocks versus depth. The parameters of Athy's law defining the best compaction models for the Brent Group and the Statfjord Fm are presented in Table 3.

$\varnothing\left(z_{e}\right)=\varnothing_{0} e_{e}^{-(k z)}$

$Z_{e}$ : hydrostatic depth, $\varnothing_{0}$ : initial porosity, $\varnothing\left(z_{e}\right)$ : final porosity at $Z_{e}, k$ : Athy's parameter (compaction coefficient).

\section{Fault definition}

The faults are imported into the model as fault surfaces obtained from 3D seismic cubes, used to build fault planes and fault maps. This fault map is assigned to the Brent Group and the layers below it. The fault planes and fault surfaces were digitized using the SeisStrat module in PETROMOD before incorporating them into the model. Ten fault intersections are selected for detailed fault properties modelling due to their proximity to the hydrocarbon 

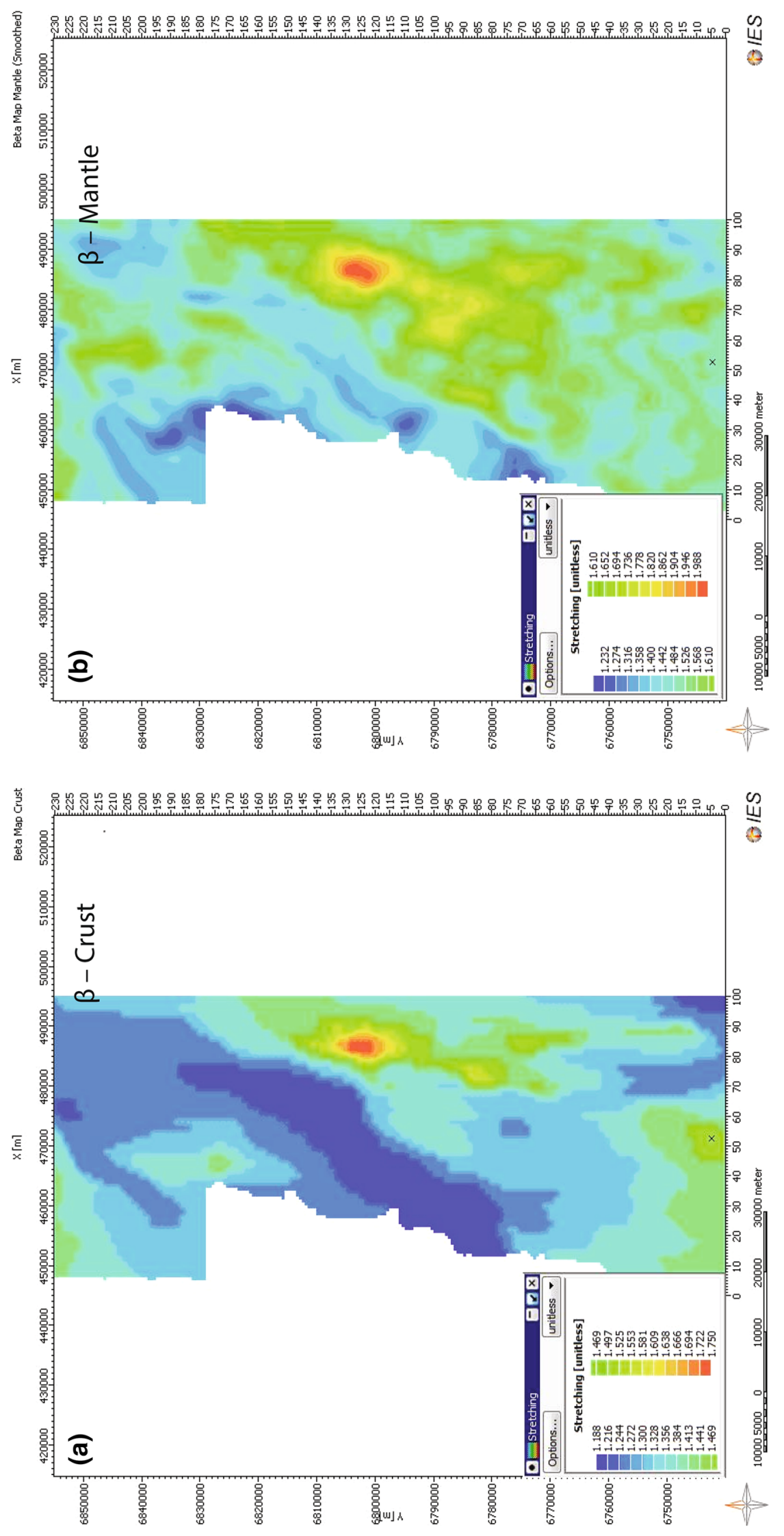

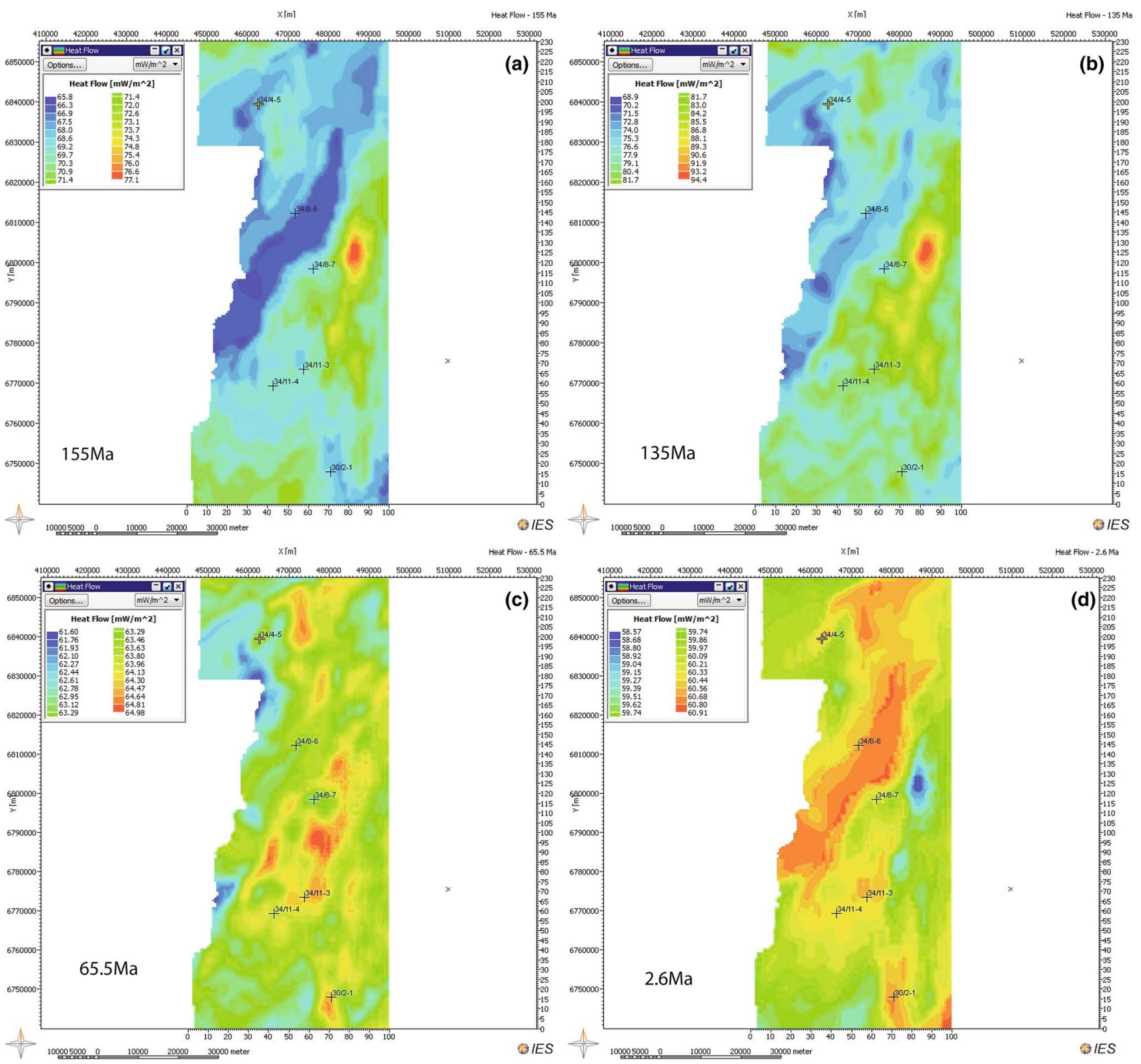

Fig. 3 Paleo-heat flow distribution across the modelled basin a $155 \mathrm{Ma}$; b $135 \mathrm{Ma} ;$ c $65.5 \mathrm{Ma}$; $2.6 \mathrm{Ma}$

Table 3 Compaction model parameters

\begin{tabular}{lll}
\hline Parameters & Brent group & Statford Fm \\
\hline Initial porosity (\%) & 45 & 50 \\
Minimum porosity (\%) & 5 & 5 \\
Compaction coefficient $\left(\mathrm{km}^{-1}\right)$ & 0.22 & 0.27 \\
\hline
\end{tabular}

accumulations (Fig. 4). The ages of faults are set from 135 to $0 \mathrm{Ma}$. Three types of fault behaviour were incorporated in the modelling and the results calibrated against the hydrocarbon-in-place in Gullfaks, Visund, Huldra and Kvitebjørn fields (Table 4). The first two scenarios of fault behaviour are the two extreme cases where all the faults are opened in one model and in the other model all the faults are closed. The third fault scenario involves varying the gamma ray-log calculated SGR values of each fault until the hydrocarbon-in-place in all the fields is obtained simultaneously. This model represents the most probable migration scenario.

\section{Model calibration}

Once the model is built, the next phase is to calibrate the heat flow model with the temperatures of the formations present in the wells or with thermal maturity data such as 
Fig. 4 Faults map and selected assigned faults

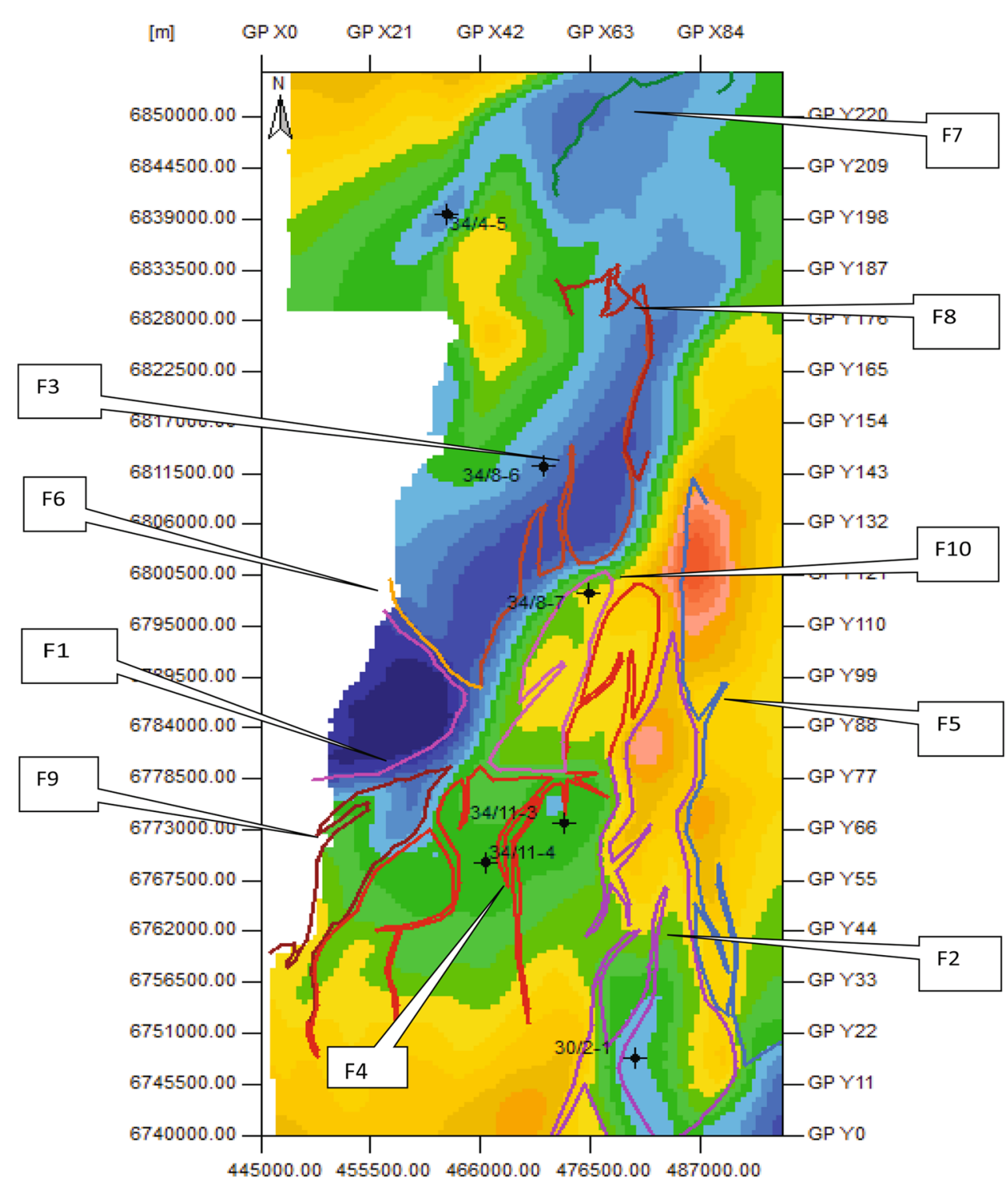

Table 4 Hydrocarbons originally in place in the studied fields

\begin{tabular}{lll}
\hline Fields & \multicolumn{2}{l}{ Hydrocarbon originally in-place } \\
\cline { 2 - 3 } & $\begin{array}{l}\text { Oil }\left[\mathrm{Mm}^{3} \text { oil equivalent }\right. \\
(\text { o.e })]\end{array}$ & $\begin{array}{l}\text { Gas }\left[\mathrm{Mm}^{3}\right. \\
\text { oil equivalent } \\
(\text { o.e })]\end{array}$ \\
\hline Gullfaks & 581 & \\
Visund & 90 & 82 \\
Kvitebjørn & & 39 \\
Huldra & & \\
\hline
\end{tabular}

vitrinite reflectance. The heat flow model calibration is important as it is one of the parameters controlling the maturity of the source rock. Vitrinite reflectance data and bottom hole temperature have been used in calibrating this model to ensure accuracy of the model.

\section{Results and discussion}

The first two models analysed in the study incorporated the two extreme cases of fault properties. In the first scenario (S1), all the selected faults are defined as open faults, whereas in the second scenario (S2), all the faults are defined as closed faults. In scenarios 3 and 4, SGR is defined as $56 \%$ and $25 \%$, respectively. The SGR option is embedded in the Petromod software and is used to define the permeability or impermeability of a fault. Faults with SGR of more than 40 are impermeable, whereas faults with SGR less than 20 are very permeable. Once the SGR values for a fault plane are determined, the fault plane is assigned to a specific layer that is affected by the fault prior to simulation. The controlling faults in the Gullfaks field are F1, F6 and F9 (Fig. 4). For the Visund field, the faults include F3, F6 and F8. F4 and F10 are the dominant faults in the Kvitebjørn field, and F2 and 
Table 5 Hydrocarbon accumulation from scenario 1 (S1) and OIP

\begin{tabular}{lllllc}
\hline Fields & \multicolumn{2}{l}{ Gas in-place $\left(\mathrm{Mm}^{3}\right.$ o.e $)$} & & \multicolumn{2}{l}{ Oil in place $\left(\mathrm{Mm}^{3}\right.$ o.e $)$} \\
\cline { 2 - 3 } \cline { 5 - 6 } & $\mathrm{S} 1$ & Reference & & $\mathrm{S} 1$ & Reference \\
\hline Kvitebjørn & 0.79 & 82 & & \\
Huldra & 0.98 & 39 & & 693 & 581 \\
Gullfaks & & & 92.64 & 90 \\
Visund & & & &
\end{tabular}

Table 6 Hydrocarbon accumulation from scenario (S2) and OIP

\begin{tabular}{|c|c|c|c|c|}
\hline \multirow[t]{2}{*}{ Fields } & \multicolumn{2}{|c|}{ Gas in-place $\left(\mathrm{Mm}^{3}\right.$ o.e $)$} & \multicolumn{2}{|c|}{$\begin{array}{l}\text { Oil in place }\left(\mathrm{Mm}^{3}\right. \\
\text { o.e) }\end{array}$} \\
\hline & $\mathrm{S} 2$ & Reference & S2 & Reference \\
\hline Kvitebjørn & 742 & 82 & & \\
\hline Huldra & 413 & 39 & & \\
\hline Gullfaks & & & 1.51 & 581 \\
\hline Visund & & & 686 & 90 \\
\hline
\end{tabular}

F5 for the Huldra field (Fig. 4). The SGR values in scenario 5 are defined to vary between 25 and $56 \%$ for the faults.

\section{Scenario 1 (S1): open faults}

In this scenario, all other parameters in the base model are kept constant and the faults defined as open/non-sealing faults. This scenario results in very small hydrocarbon accumulations in the Kvitebjørn and Huldra fields $\left(0.79 \mathrm{Mm}^{3}\right.$ and $0.98 \mathrm{Mm}^{3}$ o.e, respectively) compared to the actual oil-in-place (OIP) in those fields (Table 5). The volume of hydrocarbons obtained in the Gullfaks and Visund fields in scenario 1 is $693 \mathrm{Mm}^{3}$ o.e and $92.64 \mathrm{Mm}^{3}$ o.e compared to the actual oil-in-place in the two fields which is $581 \mathrm{Mm}^{3}$ o.e and $90 \mathrm{Mm}^{3}$ o.e, respectively (Table 5).

The hydrocarbon accumulations in the Gullfaks and Visund fields obtained from the model are therefore quite close to the actual oil-in-place. Scenario 1 therefore results in similar volumes of hydrocarbon accumulation in the Gullfaks and Visund fields; however, because the model does not give the right accumulations in the Kvitebjorn and Visund fields, it is discounted as the most likely fault properties scenario in the area.

\section{Scenario 2 (S2): closed faults}

In this scenario, all other parameters in the base model are kept constant and the faults defined as closed/sealing faults. The definition of the faults as closed faults results in the accumulation of large volumes of hydrocarbons trapped along the faults. The gas accumulated in Kvitebjørn and Huldra fields is $742 \mathrm{Mm}^{3}$ o.e and $413 \mathrm{Mm}^{3}$ o.e
Table 7 Hydrocarbon accumulation from scenario 3 (S3) and OIP

\begin{tabular}{|c|c|c|c|c|}
\hline \multirow[t]{2}{*}{ Fields } & \multicolumn{2}{|c|}{ Gas in-place $\left(\mathrm{Mm}^{3}\right.$ o.e $)$} & \multicolumn{2}{|c|}{$\begin{array}{l}\text { Oil in place }\left(\mathrm{Mm}^{3}\right. \\
\text { o.e) }\end{array}$} \\
\hline & S3 & Reference & S3 & Reference \\
\hline Kvitebjørn & 742 & 82 & & \\
\hline Huldra & 405 & 39 & & \\
\hline Gullfaks & & & 74 & 581 \\
\hline Visund & & & 422 & 90 \\
\hline
\end{tabular}

which is several orders higher than actual gas-in-place of $82 \mathrm{Mm}^{3}$ o.e and $39 \mathrm{Mm}^{3}$ o.e, respectively (Table 6). The oil accumulation obtained from the model in the Gullfaks and Visund fields is $1.51 \mathrm{Mm}^{3}$ o.e and $686 \mathrm{Mm}^{3}$ o.e, respectively. Consequently, the oil accumulation in Gullfaks field is underestimated, whereas the accumulation in Visund field is overestimated. In the case of the Gullfaks field, the huge underestimation of the hydrocarbon volume by the model is attributed to the fact that the sealing faults trapped hydrocarbons migrating into the reservoir from the source rocks and may have not reached the Gullfaks field. In the case of the Kvitbjorn, Huldra and Visund fields where there is overestimation of hydrocarbon volumes by the model, the hydrocarbons may not have been trapped during migration from the source rocks into the reservoir but are trapped only after reaching the reservoir. The model in S2 therefore also discounts closed faults as the right fault property for the faults controlling hydrocarbon accumulation in the basin.

\section{Scenario 3: $\mathrm{SGR}=56 \%$}

This scenario is aimed at narrowing down the SGR properties of the faults since the results from scenarios 1 and 2 indicate that all the faults are neither opened nor closed. An SGR of $56 \%$ is used representing the average SGR of open faults ( $\mathrm{SGR}=18 \%)$ and closed faults $(\mathrm{SGR}=95 \%)$. Even though faults F3, F6 and F8 defined as opened faults in scenario 1 gave the right accumulation, SGR for these faults is also defined as $56 \%$ in this scenario to confirm the properties of the faults controlling accumulation in the Visund field. The gas accumulated in Kvitebjørn and Huldra fields is $742 \mathrm{Mm}^{3}$ and $405 \mathrm{Mm}^{3}$ o.e, respectively.

The oil accumulated in Gullfaks and Visund fields is $74 \mathrm{Mm}^{3}$ o.e and $422 \mathrm{Mm}^{3}$ o.e, respectively (Table 7). Analysing this result, the gas in Kvitebjørn and Huldra fields and the oil in Visund field are overestimated, whereas the oil accumulated in Gullfaks field is underestimated. Results from scenario 3 therefore indicate that the faults controlling hydrocarbon accumulation in Kvitebjorn, Huldra and Gullfaks may be more opened than defined in this scenario allowing further migration of hydrocarbons from the reservoir rocks. This result also confirms that faults F3, F6 and 
Table 8 Hydrocarbon accumulation from scenario 4 (S4) and OIP

\begin{tabular}{lcclcc}
\hline Fields & \multicolumn{2}{l}{ Gas in-place $\left(\mathrm{Mm}^{3}\right.$ o.e $)$} & & \multicolumn{2}{l}{ Oil in place $\left(\mathrm{Mm}^{3}\right.$ o.e $)$} \\
\cline { 2 - 3 } \cline { 5 - 6 } & S4 & Reference & & S4 & Reference \\
\hline Kvitebjørn & 23 & 82 & & \\
Huldra & 9 & 39 & & & \\
Gullfaks & & & & & \\
Visund & & & & 94 & 90 \\
\hline
\end{tabular}

F8 controlling hydrocarbon accumulation in the Visund field are most likely open/non-sealing faults as initially defined in scenario 1 .

\section{Scenario 4: SGR $=\mathbf{2 5} \%$}

Considering the results of scenarios 1, 2 and 3, the faults in this scenario are defined as more open with an SGR of 25\% except faults F3, F6 and F8 in Visund field. The gas accumulations obtained for Kvitebjørn and Huldra fields are $23 \mathrm{Mm}^{3}$ o.e and $9 \mathrm{Mm}^{3}$ o.e, respectively, which is less than the actual gas-in-place (Table 8). For the case of Gullfaks field, the amount of oil is overestimated as $1362 \mathrm{Mm}^{3}$ o.e. The result from this scenario and all the previous scenarios show that the hydrocarbon volumes are very sensitive to the SGR values and that the SGR for the faults is not the same. This means a different SGR for each fault needs to be defined. This brings us to the most likely model of the fault properties controlling hydrocarbon accumulation in the four fields.

\section{Scenario 5: the most likely model}

Results from the previous modelling in the four scenarios above confirm that the hydrocarbon accumulations in each of the four fields are controlled mainly by the faults nearest to the fields. The following deductions are made from the four previous scenarios.

- The fault controlling the gas-in-place in Kvitebjørn field is F4

- The faults controlling the gas-in-place in Huldra field are F2 and F5.

- The faults controlling the oil-in-place in Visund fields are F3, F6 and F8.

- The fault controlling the oil-in-place in Gullfaks fields is F1, F6 and F9.

- Fault 10 does not contribute significantly to hydrocarbon accumulation in any of the four fields.

Considering the results above, the SGR of faults F2, F4 and F5 is set between 25 and 56\%. F4 controlling accumulation in Kvitebjørn is set as SGR $=30 \%$, whereas F2 and
Table 9 Hydrocarbon accumulation from scenario 5 (S5) and OIP

\begin{tabular}{llllll}
\hline Fields & \multicolumn{2}{l}{ Gas in-place $\left(\mathrm{Mm}^{3}\right.$ o.e $)$} & & \multicolumn{2}{l}{ Oil in place $\left(\mathrm{Mm}^{3}\right.$} \\
& & & & o.e $)$ & \\
\cline { 2 - 3 } \cline { 5 - 6 } & S5 & Reference & & S4 & Reference \\
\hline Kvitebjørn & 95.58 & 82 & & & \\
Huldra & 40.48 & 39 & & & \\
Gullfaks & & & & 694 & 581 \\
Visund & & & & 93 & 90 \\
\hline
\end{tabular}

F5 controlling the accumulation in Huldra field are set as SGR $=40 \%$ and open fault, respectively. For Visund field, the properties of the faults F3, F6 and F8 are defined as open faults as already established from the earlier scenarios. After several test runs, the SGR of Gullfaks field is set as $10 \%$ for F1, closed for F9 and open for F6. In this scenario, the accumulated gas in Kvitebjørn and Huldra fields is $95.58 \mathrm{Mm}^{3}$ o.e and $40.48 \mathrm{Mm}^{3}$ o.e, respectively (Table 9). In Gullfaks and Visund fields, the hydrocarbon volumes obtained from the model are $695 \mathrm{Mm}^{3}$ o.e. and $95.75 \mathrm{Mm}^{3}$ o.e, respectively. The hydrocarbon accumulations obtained from this scenario are therefore the closest to the actual accumulations and represent the most likely fault properties model in the study area.

By narrowing down these faults properties from the different scenarios, the most likely model reflecting the geological reality of the northern North Sea region is most likely scenario 5 (Fig. 5) with the following faults properties:

- For the fault controlling Kvitebjørn field which is F4, the SGR is equal to $30 \%$. If the fault is defined by SGR less than $30 \%$, the gas in the field is underestimated. On the other hand, if it is defined with SGR greater than 30\%, the accumulation will be overestimated. Comparing S4 where $\mathrm{F} 4$ is defined by SGR $=25 \%$, and S5 where F4 is defined by SGR $=30 \%$, there is a large difference of $72 \mathrm{Mm}^{3}$ o.e between the two scenarios.

- For the faults controlling Huldra field which are F2 and F5, the properties of the faults are set as SGR $=40 \%$ for F2 and open fault for F5.

- For the faults controlling Visund field which are F3, F6 and F8, the properties of all of these faults are set as open faults.

- For the faults controlling the Gullfaks field which are F1 and F9, the SGR is 10\% and closed, respectively.

After several simulations, it is determined that fault F10 has no effect on the fields.

It is observed from the simulations that any small variation of shale gouge ratio of fault controlling the gas accumulation might lead to a very large difference in volume of hydrocarbons obtained. It might be possible to state that the 


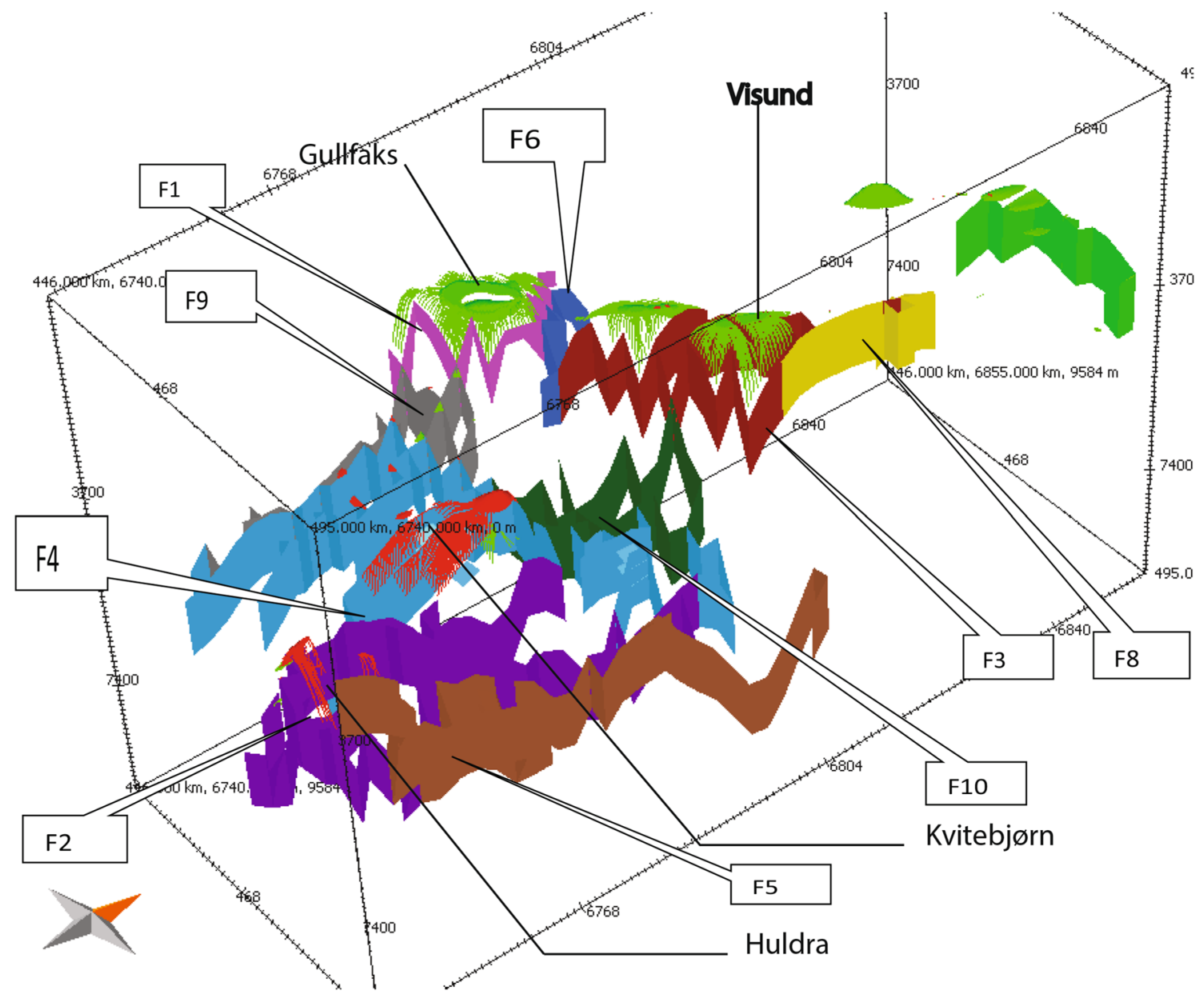

Fig. 5 Hydrocarbon accumulations from the most likely model (scenario 5)

gas accumulation is very sensitive to shale gouge ratio. This can be explained by the mobility of the gas. Another observation is that in general, by closing the fault, more accumulation is observed than opening the fault. Nevertheless, this hypothesis is not always verified. For instance, in Gullfaks field, by closing the fault F9, less accumulation is observed, whereas by opening the fault, the accumulation is overestimated. Therefore, by setting up the fault properties as open or closed, the result accumulation depends on conditions of migration pathways such as the complexity of the geological structures within the area or the migration timing.

\section{Conclusion}

In this research, faults properties that control hydrocarbon accumulation have been investigated using the Gullfaks, Visund, Kvitebjørn and Huldra fields in the North Sea. A most likely model representing the reality and the fault properties suggested has been proposed and presented in order to have a better understanding of the petroleum system in the northern North Sea. The hydrocarbons in place in these fields are mainly controlled directly by their adjacent faults with different properties with some exception. For instance, in Gullfaks field, the fault controlling the hydrocarbon accumulation is the fault bounding the field which is relatively non-sealing fault with SGR $=10 \%$. It is also controlled by another fault located further south of the field (F9) which is a closed fault since defining it as an open fault leads to overestimation of hydrocarbon accumulation in the field. The Visund field is controlled by the NE-SW faults which are non-sealing. The Kvitebjørn field is controlled by the fault surrounding the field with $\mathrm{SGR}=30 \%$. The main fault with $\mathrm{N}-\mathrm{S}$ trend controlling hydrocarbon accumulation in the Huldra field has SGR $=40 \%$. After analysing these faults, it is concluded that the fault properties have an important influence on the migration pathways from the source rock to the reservoir rock particularly the SGR values. Depending on the geological context of the study area, both open and closed faults might lead to a high or low accumulation. In addition, it is observed that in the case of gas fields, the 
accumulation is more sensitive to SGR than the oil accumulation due to the easier mobility of gas.

Acknowledgements The authors would like to thank SINTEF Petroleum, Trondheim, Norway, for providing the data used in this research.

Open Access This article is distributed under the terms of the Creative Commons Attribution 4.0 International License (http://creativeco mmons.org/licenses/by/4.0/), which permits unrestricted use, distribution, and reproduction in any medium, provided you give appropriate credit to the original author(s) and the source, provide a link to the Creative Commons license, and indicate if changes were made.

\section{References}

Ben-Awuah J, Adda GW, Mijinyawa A et al (2013) 2D Basin modelling and petroleum system analysis of the triassic play in the hammerfest basin of the norwegian barents sea. Res J Appl Sci Eng Technol 6:3137-3150

Ben-Awuah J, Andriamihaja S, Mijinyawa A et al (2014) Effect of some input parameters on 3D basin and petroleum systems modelling: a case study of the Norwegian section of the Northern North Sea. Res J Appl Sci Eng Technol 7:3746-3762

Burnham A (1989) A simple kinetic model of petroleum formation and cracking. Geochim Cosmochim Acta 43:1-11

Childs C, Sylta Moriya S et al (2009) Calibrating fault seal using a hydrocarbon migration model of the Oseberg Syd area. Mar Pet Geol, Viking Graben. https://doi.org/10.1016/j.marpe tgeo.2008.05.004

Dahl N, Solli T (1993) The structural evolution of the Snorre Field and surrounding areas. In: Pet Geol Northwest Eur Proc 4th Conf Pet Geol NW Eur Barbican Centre, London. https://doi. org/10.1144/0041159

Davies RK, An L, Jones P et al (2003) Fault-seal analysis South Marsh Island 36 field. Am Assoc Pet Geol Bull, Gulf of Mexico. https:// doi.org/10.1306/08010201133

Evans D, Armour A, Bathurst P et al (2003) Introduction and database. In: Evans D, Graham C, Armou A, Bathurst P (eds) The millennium atlas: petroleum geology of the central and northern North Sea. The Geological Society of London, London, pp 11-15

Fulljames JR, Zijerveld LJJ, Franssen RCMW (1997) Fault seal processes: systematic analysis of fault seals over geological and production time scales. Nor Pet Soc Spec Publ. https://doi. org/10.1016/s0928-8937(97)80006-9

Halland EK, Riis F (2014) Evaluation of $\mathrm{CO}_{2}$ storage possibilities on the Norwegian Continental Shelf. Energy Procedia 63:5192-5199

Hantschel T, Kauerauf AI (2009) Fundamentals of basin and petroleum systems modeling. Springer, Berlin

Husmo T, Hamar GP, Hoiland O, Johannessen EP, Romuld A, Spencer AM, Tintterton R (2002) Lower and Middle Jurassic. In: Evans D, Graham C, Armou A, Bathurst P (eds) The millennium atlas: petroleum geology of the central and northern North Sea. The Geological Society of London, London, pp 129-155
Johnson HD, Fisher MJ (1998) Geological controls of North Sea hydrocarbon plays. Pet Geol North Sea basic concepts Recent Adv Blackwell Sci Publ, pp 463-547

Johnson HD, Krol DE (1984) Geological modeling of a heterogeneous sandstone reservoir: Lower Jurassic Statfjord formation. Proc SPE Annu Tech Conf Exhib, Brent Field. https://doi. org/10.2523/13050-MS

Kirk RH (1979) Statfjord field, North Sea gian. Am Assoc Pet Geol Bull 63:479-480

Kubala M, Bastow M, Thompson S et al (2003) Geothermal regime, petroleum generation and migration. In: Evans D, Graham C, Armou A, Bathurst P (eds) The millennium atlas: petroleum geology of the central and northern North Sea. The Geological Society of London, London, pp 289-315

KyrkjebØ R, Gabrielsen RH, Faleide JI (2004) Unconformities related to the Jurassic-Cretaceous synrift-post-rift transition of the northern North Sea. J Geol Soc London 161:1-17

Lindsay NG, Murphy FC, Walsh JJ et al (1993) Outcrop studies of shale smears on fault surfaces. Geol Model Hydrocarb Reserv outcrop Analog 15:113-123

Moretti I, Deacon K (1995) Subsidence, maturation and migration history of the Tampen Spur area. Mar Pet Geol 12:345-375. https:// doi.org/10.1016/0264-8172(95)96900-b

Nadin PA, Kusznir NJ (1995) Palaeocene uplift and Eocene subsidence in the northern North Sea Basin from 2D forward and reverse stratigraphic modelling. J Geol Soc Lond 152:833-848

Perkins H (1961) Fault closure-type fields, southeast Louisiana. Trans Gulf Coast Assoc Geol Soc 11:177-196

Røe SL, Steel R (1985) Sedimentation, sea-level rise and tectonics at the Triassic-Jurassic boundary (Statfjord Formation), Tampen Spur, Northern North Sea. J Pet Geol 8:163-186. https://doi. org/10.1111/j.1747-5457.1985.tb01009.x

Spencer AM, Larsen VB (1990) Fault traps in the northern North Sea. Geol Soc Lond Spec Publ 55:281-298

Underhill JR, Partington MA (1993) Jurassic thermal doming and deflation in the North Sea: implications of the sequence stratigraphic evidence. In: Parker JR (ed) Petroleum geology of Northwest Europe: Proceedings of the 4th conference. The Geological Society of London, London, pp 337-345

Vollset J, Dore a G (1984) A revised Triassic and Jurassic lithostratigraphic nomenclature for the Norwegian North Sea. Nor Pet Dir Bull

Yielding G, Freeman B, Needham DT (1997) Quantitative fault seal prediction. Am Assoc Pet Geol Bull. https://doi. org/10.1306/522b498d-1727-11d7-8645000102c1865d

Zanella E, Coward MP (2003) Structural framework. In: Evans D, Graham C, Armour A, Bathurst P (eds) The millennium atlas: petroleum geology of the central and northern North Sea. The Geological Society of London, London, pp 45-59

Publisher's Note Springer Nature remains neutral with regard to jurisdictional claims in published maps and institutional affiliations 